DIGITAL COMMONS
@ UNIVERSITY OF SOUTH FLORIDA

Volume 10

Issue 2 Fall 2020

2020

\title{
Beyond Victims \& Villains: Teaching Cleland With Haywood \& Behn
}

Christopher Nagle

Western Michigan University, cnagle@wmich.edu

Follow this and additional works at: https://digitalcommons.usf.edu/abo

Part of the Dramatic Literature, Criticism and Theory Commons, Educational Methods Commons, Feminist, Gender, and Sexuality Studies Commons, and the Literature in English, British Isles Commons

\section{Recommended Citation}

Nagle, Christopher (2020) "Beyond Victims \& Villains: Teaching Cleland With Haywood \& Behn," ABO: Interactive Journal for Women in the Arts, 1640-1830: Vol.10: Iss.2, Article 6.

http://doi.org/10.5038/2157-7129.10.2.1239

Available at: https://digitalcommons.usf.edu/abo/vol10/iss2/6

This Pedagogy is brought to you for free and open access by Digital Commons @ University of South Florida. It has been accepted for inclusion in ABO: Interactive Journal for Women in the Arts, 1640-1830 by an authorized administrator of Digital Commons @ University of South Florida. For more information, please contact digitalcommons@usf.edu. 


\title{
Beyond Victims \& Villains: Teaching Cleland With Haywood \& Behn
}

\begin{abstract}
This essay explores strategies for teaching Cleland's Memoirs of a Woman of Pleasure (Fanny Hill) in the introductory literature classroom, and why it might be especially valuable to do so at a time when issues surrounding sexual violence, rape culture, and the politics of consent continue to be prominent inside and outside the college classroom.
\end{abstract}

\section{Keywords}

John Cleland, Eliza Haywood, Aphra Behn, teaching, pedagogy, feminist, sexuality, theory, \#MeToo

Creative Commons License

(c) (i) (9)

This work is licensed under a Creative Commons Attribution-Noncommercial 4.0 License

\section{Cover Page Footnote}

I owe a genuine debt to Kirsten Saxton and Karen Gervitz, exceptionally generous and insightful readers of this essay, and to Susan Freeman, friend and collaborator over many years, for inspiring discussions and advice before, during, and after the multiple incarnations of this class. Briana Asmus has been its first and last reader, and helped me to clarify what matters most, as always. 


\section{Beyond Victims \& Villains: Teaching Cleland with Haywood \& Behn}

Despite its myriad pedagogical challenges, I believe that John Cleland's Memoirs of a Woman of Pleasure (commonly called Fanny Hill), is an ideal text for the twenty-first century undergraduate classroom precisely because it centers our attention on the complex connections between literary style and sexual politics, and elicits the reader's active engagement with the pedagogical nature of erotic narrative. The ideas in this essay were first explored in a roundtable contribution for a timely session on "Pedagogies of Consent" organized by Nick Miller for the annual meeting of the American Society for Eighteenth Century Studies in March 2020, one of innumerable conference cancellations in our new pandemic era. At my own university, the spring semester ended abruptly around the same time, and the new protocols of instant conversion to distance education led me to reflect on my previous semester of face-to-face instruction with a measure of perhaps predictable nostalgia. This earlier term included my course on "Literature in the Age of \#MeToo," an introductory undergraduate English class for non-majors that featured discussion of literary works framed theoretically by analysis of the unstable and often violent dynamics of gender and sexuality from around 1667-2017, and it included Cleland and a variety of other eighteenth-century writers.

The idea for this course draws inspiration from collaborative work undertaken in an ongoing interdisciplinary research group, co-directed since 2016 with my colleague Susan Freeman, which is devoted to critical engagement with narratives of sexual violence (historical and contemporary). I wanted to craft a course that would allow students to explore some of the same issues that continue to sustain this group of teachers, researchers, and professional staff at our university, issues that are both timely and urgent. Although faculty have the freedom to craft a specific theme for our introductory literature courses, the basic expectations include sustained attention to substantial reading and writing assignments and exposure to all of the traditional literary genres. Guided by my own training in both English and Gender and Women's Studies, the main outcomes I seek here are to challenge the seductively familiar and too comfortable binary logic to which conversations about sexual violence and the politics of consent too often fall prey, both in the classroom and in popular media (e.g., news, entertainment, social media, and the many forms in which they overlap).

The concept for my course and its own critical framework draws from the growing body of interdisciplinary academic work responding to rape culture and the ongoing \#MeToo moment, much of it coming from fields such as sociology, media studies, history, critical legal studies, philosophy, and gender and sexuality studies. A few recent books with ideas that I have found especially useful to draw from in teaching this literature class include Kate Manne's work on the logic of misogyny, Linda Martín Alcoff's application of epistemic friction to sexual violation, and Joseph Fischel's queer revisionary approach to the politics of consent. The latter specifically has informed my approach in this essay, providing a powerful critique of the insufficiency of the consent paradigm (outside a legal framework) and opening up a more richly nuanced elaboration of the consistently unequal dynamics of sexual predation. These dynamics set the stage for events in which sexual autonomy is denied, most often for women, regardless of whether consent is freely given or not. Fischel also offers an alternative focus on what he calls "undemocratic hedonism," a structural condition of our culture that points to the central "problem of asymmetrical sexual access" (173). Like many other feminist scholars, this trio of 
philosophically trained thinkers shares a belief that naming and shaming perceived villains while seeking to protect those seen as victims often will feel satisfying, but it will not get us closer to systemic change. To be clear, I do not include these critical texts in my undergraduate course readings, nor do I generally introduce my intro students to these specialized terms; rather, these materials have provided part of the theoretical grounding that informs my pedagogical approach to the class.

There are many challenges and potential pitfalls in a class such as this one, especially when its disciplinary home is English rather than, say, Gender and Women's Studies. I have taught related courses in both departments, and I would simply note that I find GWS students (majors in particular) quite prepared for conversations about sexual violence as well as the ideologically fraught constructions of gender and sexuality. For other students who take this special topics version of Introduction to Literature, many of whom seek the course to fulfill a general education requirement, I begin with something of a fair-warning disclaimer regarding the content: the specific challenges of reading, discussing, and writing about sexual violence, and generally engaging with primary material that is sometimes relentlessly explicit. In the interest of supporting students who are survivors themselves - statistics make it clear that some surely will be-I provide links and contact information for professional resources (counseling, testing, advocacy, etc.), both on and off campus, at the outset. And the ground rules of respectful treatment of each other are even more crucial in this class so I emphasize those expectations accordingly. I want each class meeting to be a space in which genuine discovery can take place, which requires a space in which students feel respected and safe from attack, but also one in which it is safe to risk making embarrassing mistakes that we would all rather avoid. The second piece of fair-warning I provide is an explanation of why we are focused on this content at all. Rather than reading narrowly for representations of sexual violence, coercion, and other genderbased depredations, I explain that our aim is to look at a wide range of texts spanning from the Restoration to the present and to consider (quoting from the syllabus) "how these dynamics play a role in our literary works, how they shape them, what difference it makes that they are there, and what significance they should have to us as readers in the twenty-first century."

I begin with works from the Restoration-libertine poetry by Behn and Rochester, a play such as The Rover (Part I) - and then move on to short fiction by Haywood (Fantomina is a predictable favorite). What might be less expected than these popular choices is the more problematic text on which I wish to focus here, after first establishing a bit of context: Cleland's Memoirs of a Woman of Pleasure. I have found that class discussions - both online and face-to-face - have been especially strong when students dig into the complexities of fictional narrative that are inevitably new to them. Discussions about both Memoirs and its predecessor Fantomina tend to be particularly productive, especially after being set up by previous conversations about The Rover. This sequence of texts allows us first to look closely at the uneven distribution of misogyny manifested in different forms of toxic masculinity in Behn's play. Each female character experiences this misogyny differently, in part based on her real or perceived class status. It is always instructive, for example, to compare the two near-rapes of Florinda, first at the hands of Willmore (Act 3, Scene 5) and then later in Blunt's quarters (Act 4, Scene 5), both of which trade in the confusion between identifying a "harlot" and "a maid of quality," to darkly comic dramatic ends. I try to remind my students that we are reading a comedy - and reiterate the key features one expects to find in such a play_while encouraging them to assess what is 
different about these and other instances of mistaken identity. In one sense, they expose the dangers that are not immediately evident in a carnival setting featuring masquerading characters, of course. But close attention also leads to the unavoidable reality that the consequences are quite different for men and for women. This insight is underscored as well by the comic nuptial resolution, which "rewards" Hellena with the rakish Willmore-both of whom have resisted marriage - while the play has previously consigned the courtesan-heroine Angellica to an unknown (perhaps tragic?) fate off-stage.

We proceed by exploring Fantomina's comparative freedom to stage the scenes of her own creatively fulfilled desires, which always seems striking or even shocking to my students. Borrowing an idea from Margaret Case Croskery, I present my students with the potential conflict between Fantomina's powerful pursuit of female desire and the question of her agency in the face of these desires. I do this for two reasons: first, I hope to avoid both simple celebration of her sexual freedom as well as any reductive moralism about her exploits. Usually I find students more judgmental about her duping of Beauplaisir (perhaps an example of what Manne calls "himpathy") than about her openly seeking sexual satisfaction outside of a conventional marriage relationship. But neither response, pro or con, does justice to the tale's complexity and the interesting moral and cultural questions it raises. Second, I plan for this conversation to anticipate similar questions relevant to our reading of Cleland. So while the end of Haywood's narrative seems to shut down and perhaps even to negate all the remarkable adventures that have come before, nevertheless the narrator's cryptic last line refuses to pass moral judgment about the remarkable "Intreague" that has preceded it. My students tend to see the endings of any narrative as providing the last word not only structurally but also thematically, so the more we press on the rushed nature or the possible readerly dissatisfaction with the tale's conclusion, the better positioned we are to look critically at the ways that Fanny Hill makes meaning of her life, her adventures, and her character.

After Behn's play and Haywood's novella, most of my students come to Cleland's Memoirs very much wanting to find a heroine in Fanny Hill, and to celebrate the choices she is able to make for herself, her relative autonomy, resilience, and hard-won successes, especially in the second volume of the book. I have taught Cleland's novel in various undergraduate and graduate offerings over the years and with varying degrees of success. In my experience the particular challenges posed by this book extend far beyond the obvious but important question about how one presents, contextualizes, and opens up productive conversation about an early modern pornographic work. I generally choose to treat the explicit sexual content matter-of-factly, while pressing students to focus on the elements of literary narrative that might initially escape their attention: how is the sexual activity described, for whose benefit, and to what effect? What kinds of ethical questions are raised (or evaded) in the narrative? Are there productive ways of reading attentively for non-sexual (or not solely sexual) dynamics, such as those of friendship, mentorship, or even a kind of entrepreneurship, as well as basic drives for survival or adventure? And a main priority for me as well as a key challenge for students: what might readers (then and now) make of the question of tone? This latter question has proven especially difficult for less experienced readers who struggle to hear irony or to spot the ambiguity and inconsistency in an early modern literary work. 
We begin by considering the framing of the narrative - and I will have already provided background for them on the origins of the English novel, its evolving conventions, and readerly expectations (both in the period as well as how those are likely to differ for readers today). It is especially important to note at the outset of class discussion how Fanny sets the stage for her "memoirs," so I guide my students' attention both to the addressee (and the loose epistolary frame) as well as Fanny's insistence on "stark naked truth" - the latter, one of our first cues to Cleland's "use of suggestive double-meaning" (55), as Terry and Williams put it. In a course devoted to eighteenth-century literature I likely would draw connections to Fielding's Shamela here (Peter Sabor calls attention to these echoes throughout his edition), but for an intro group I am happy simply to calibrate readerly attention to possible punning wordplay and eventually to the rich catalog of metaphorical language devoted to sexual organs and activities. Students can find this linguistic expansiveness tiresome and a bit perplexing, so it is vital to discuss the purpose of this serious playfulness. Returning to Fanny's own reflections on the unavoidable repetition of her subject at the beginning of volume 2 is a perfect place to start, asking students to reflect on why she does so, what effect that might have on our readerly response, and whether in fact her purpose could be seen as pedagogical.

Much of the richest and most passionate discussion with students tends to emerge from our focus on the second volume of the novel and its conclusion. Three specific elements tend to complicate their desire to read for a happy ending that neatly ties together Fanny's story: (1) her random, dangerous street tryst with a sailor (a rare instance of non-transactional sex without the ennobling narrative of love); (2) her almost unaccountably moralistic vitriol for the sodomites she spies upon at the public-house and intends to expose to "justice" (most likely: a gruesome death); and (3) the ending itself as Fanny doubles down on her excuse for "paint[ing] vice all in its gayest colours" so that her alleged moral conversion will seem all the more powerful. The first two examples address conduct that, while consensual, Fanny perceives as problematic or fully depraved even amidst the endless catalog of debauchery and nonnormative sexual expression that fills her world. For this reason they often serve as puzzling stumbling blocks for my students - in part because, despite both scenarios being consensual, Fanny is not clearly in control of herself either as actor or as voyeur. Here is one of many examples of a productive contrast to Fantomina's earlier compulsive exploits.

The question of the novel's ending is perhaps even more instructive, as it helps us to decenter consent as one of the primary or most valuable considerations in our analysis. Given Fanny's audience to whom this narrative is addressed (first, a female friend addressed simply as "Madam"; then, those of us reading the book), and given $99 \%$ of the novel's content, how is this sudden assertion of conventional morality to be taken? Quite often, I find that students take it surprisingly seriously, despite Fanny's periodic inconsistencies, her selectiveness about what to share and what to leave out, her playfulness with language, and her self-consciousness about narrative conventions that at one point invites us to equate writing with prostitution (by extension, making the reader a john). All of these more difficult questions - matters seldom taken up by an introductory group of students on their own - are vital to raising the related question of how our own role as readers may be compromised. Is it fair to assume that the fictional female recipient of Fanny's letters has consented to this extensive pornographic narrative? Or that we as readers of Cleland's novel have done so when we first take it up? If we continue to read (without coercion), then that consent seems to be implied, but of course 
assigning this novel as a required course text complicates that notion fundamentally-perhaps especially so for non-majors who are less familiar with the conventions of literary representation (and often, less enthusiastic in approaching early modern texts at all).

What I hope most to see in class discussions is an increased willingness and ability to extend the complexities of literary and political analysis to questions about sexual politics and ethics. As Kirsten Saxton has noted, the pleasurable tension produced by the novel's libertine and bourgeois investments usefully points readers to early modern English obsessions as well as those often shared by contemporary American readers. The easiest and least thoughtful response to a work like Fanny Hill (or Fantomina or The Rover) - just as in opinion pieces about celebrity predators in our daily news - is to adopt a knee-jerk, black-and-white response that focuses on victims and villains. This response is both intellectually and ethically inadequate, veering between fixing blame and signaling empathy. If we are to do justice to the complexities of lived experience, especially that of survivors of sexual violence, we need to explore the systemic structures of power that run unevenly - both in literature and in life - so that a concept such as consent, as valuable as it is, does not provide the horizon of limitations for how we imagine sexual freedom in Cleland's age or in our own.

The closing question of Fischel's book is one that I want my students to wrestle with when thinking about our literary works, from Rochester to Behn to Haywood to Cleland to Sade: "How might we democratize sexual culture?" (182). One way is to abandon a more constrained sense of consent as it most usefully applies in legal cases, for a sexual politics that embraces concepts like autonomy, access, and perhaps also a genuinely "democratic hedonism" for all people, not the version we most often find that simply privileges powerful men at the expense of everyone else. We might start by looking for these elements within literary narratives of sufficient complexity that challenge us to see sexuality, narrative voice, and readerly complicity in ways that are initially unfamiliar to contemporary readers, but which nevertheless resonate profoundly in our own age as well. For all of these reasons, Cleland's entertaining and exasperating experimental novel deeply deserves and also richly rewards close attention in the college classroom, especially in the \#MeToo era.

\section{A postscript: Examples of online writing/discussion prompts for Cleland's Memoirs}

There are ways in which we might see our heroine/protagonist as both conventional and unconventional, and she certainly has particular values that she articulates as she navigates the complexity of her world. What do you ultimately make of Fanny's moral character? Explain why you see her in the way that you do.

On a more specific note: how do you understand Fanny's views regarding monogamy and fidelity? Do they seem to fit her life/lifestyle? Explain.

How do you see the narrative structure/conventions of this book to work on its reader? How does it contribute to shaping how we view the characters and their actions? (Note: a good place to return to is the opening of Part II of the book.)

\section{Coda to the postscript:}


I would note how productively this line of inquiry could be expanded for a graduate seminar by framing it with an ideal critical reading-I have in mind Kathleen Lubey's chapter on Cleland and Hogarth in Excitable Imaginations - that explores the formal properties of (and relations between) sex and reading in Memoirs, while putting the novel in conversation with other key texts by Defoe, Richardson, and Fielding in addition to Haywood. For a helpful counterweight to students' tendency to overvalue the ending of a narrative, John Beynon's stunning essay on the Sapphic dynamics of the novel also focuses on the ways that Memoirs and other pornographic writing work "against the traditional teleological models that insist upon tracing the linear progress of fiction and privileging the conclusion as the key to a fiction's ultimate meaning" (7). Additionally, one could supplement the novel with rich contextual readings drawn from prostitute narratives of the period: the Broadview edition appendices are helpful here, but for fuller and more varied selections, see Laura Rosenthal's Nightwalkers collection for examples of both libertine and sentimental narratives that span the eighteenth century.

\section{A note on texts}

When teaching Cleland's novel I have used the Oxford World's Classics edition of the unexpurgated text, edited by Sabor, which features minimal but helpful explanatory notes and a brief, useful introduction. The recent publication of a Broadview edition, edited by Richard Terry and Helen Williams, is the one I plan to use in future coursework. In addition to the typically rich contextual materials for which Broadview is known, the notes are more extensive and the edition is clearly designed with student readers in mind.

\section{Works cited}

Alcoff, Linda Martín. Rape and Resistance. Polity, 2018.

Beynon, John C. “"Traffic in More Precious Commodities': Sapphic Erotics and Economies in Memoirs of a Woman of Pleasure." Launching Fanny Hill: Essays on the Novel and Its Influences, edited by Patsy S. Fowler and Alan Jackson, AMS, 2003, pp. 3-26.

Cleland, John. Memoirs of a Woman of Pleasure, edited by Peter Sabor, Oxford UP, 2008.

---. Memoirs of a Woman of Pleasure, edited by Richard Terry and Helen Williams, Broadview, 2018.

Croskery, Margaret Case. "Masquing Desire: The Politics of Passion in Eliza Haywood's Fantomina." The Passionate Fictions of Eliza Haywood: Essays on Her Life and Work, edited by Kirsten Saxton and Rebecca Bocchicchio, Kentucky UP, 2000, pp. 69-94.

Fischel, Joseph. Screw Consent: A Better Politics of Sexual Justice. California UP, 2019. 
Lubey, Kathleen. Excitable Imaginations: Eroticism and Reading in Britain, 1660-1760. Bucknell UP, 2012.

Manne, Kate. Down Girl: The Logic of Misogyny. Oxford UP, 2018.

Rosenthal, Laura J. Nightwalkers: Prostitute Narratives from the Eighteenth Century. Broadview, 2008.

Saxton, Kirsten T. "Risking Fanny: Teaching Memoirs of a Woman of Pleasure." Launching Fanny Hill: Essays on the Novel and Its Influences, edited by Patsy S. Fowler and Alan Jackson, AMS, 2003, pp. 331-354. 